\title{
Research and Practice of the Training of Undergraduate Talent based on Numerical Control Technology of Mechanical Engineering and Automation Speciality
}

\author{
Wang Le ${ }^{a}$, Zhong Lijun ${ }^{b}$ \\ Baicheng Normal University, Baicheng, 137000, China \\ aemail: 1421464748@qq.com, bemail:jlsbcsfxy@163.com
}

Keywords: Numerical Control Technology, Mechanical Engineering, Automation

\begin{abstract}
It can be seen that the specialty of mechanical design and manufacture based on NC design and its automation is quite distinctive, and the speed of industry renewal is relatively fast, which leads to the difficulty of meeting the needs of the development of the times.In order to optimize the cultivation of relevant professional talents, we should pay attention to the reform of talent training mode, take effective measures such as setting up excellent teachers, perfecting the practical teaching platform, and cultivating students' good innovative consciousness and so on. It is of great significance to strengthen the training of talents and to promote the improvement of the quality and ability of relevant majors. In this paper, the mechanical design and manufacture based on numerical control technology and the training of professional undergraduate talents in automation are briefly discussed.
\end{abstract}

\section{Introduction}

In recent years, along with the social progress and the economic development, our country education enterprise realizes the rapid expansion and the deepening reform. Higher education from the traditional sense of elite training to the popular education training model has taken place a positive change. In the National medium and long term Education Reform and Development Program outline, colleges and universities need to pay attention to the students' moral education in an all-round way training. To strengthen the training of students' ability, to promote their all-round development into innovative talents, to devote themselves to local economic construction, to contribute a great deal of power to social development, and to fully respond to the call of the state. When training undergraduate talents of mechanical design and manufacture and automation specialty based on numerical control technology, the relevant colleges should carry out the teaching concept of combining knowledge and practice and developing morality simultaneously, and deepen the reform of the methods and means of talent training. The importance of realizing the effective enhancement of students' innovative consciousness and practical ability can not be ignored.

\section{Analysis of Mechanical Design and Manufacture based on NC Technology and the Training of Undergraduate Talents of Automation Specialty}

Target Location. Nowadays, with the rapid improvement of economic level and the rapid development of science and technology, the traditional disciplines and materials related to machinery, as well as humanities, information and other aspects of the professional boundaries are increasingly blurred. Therefore, under the background of the new era, the mechanical design and manufacture based on NC technology and its automation specialty fully meet the new requirements of teaching[1]. It is necessary to reform the training mode of undergraduate professionals in an all-round way. First of all, the primary goal of the reform is to make efforts to optimize the cultivation of high-quality professionals for enterprises and institutions. The purpose of this paper is to make the society satisfy the demands of talents, including the ability of talents, personal accomplishment, professional knowledge level and so on. Secondly, with the progress of science and technology, in order to meet the needs of the modern, we must realize the diversified 
development of talents, morality, intelligence, physical integrity, labor and labor, and make them become excellent professionals with professional basic knowledge and perfect basic skills and strong innovative ability. In this way, the production requirements of the first-line manufacturing industry can be fully met; Thirdly, the goal of modernization training must be fully displayed in the process of training professional talents. It needs to have both mechanical and electrical combination and engineering application of the two main characteristics, the purpose of talent training is to provide effective services for the manufacturing industry in the future, the scope of talent business involves management, sales and design and manufacturing. Technical transformation and application and other aspects of the content[2].

Basic Framework. According to the current situation, the basic framework of mechanical design and manufacture based on numerical control technology and the training of professional talents of automation can be roughly divided into the following aspects. First. The application of engineering is the main line; Second, the machine and electricity as two pillars; Third, reasonable design and manufacturing, measurement and control drive three aspects of the module; 4th, the humanities and mathematics and physics, foreign languages and computer technology as the basic content; 5th, the project quality and professional technology, moral quality, humanistic accomplishment, physical and mental health and other qualities as the focus of cultivation[3].

Competency Requirements. According to the related requirements of "thick foundation, wide caliber, high quality and strong application", the mechanical design and manufacture based on numerical control technology and the cultivation of professional talents of automation should pay attention to the moral, intellectual, physical and physical beauty of talents. Coordinating and unifying the talents' practical ability, professional knowledge and comprehensive accomplishment, which makes them have a good theoretical basis of discipline, complete mechanical design and manufacturing technology, foreign language, computer, etc. The consciousness of innovation has been strengthened and developed into a first-line production position in the industrial economy engaged in the research and development of mechanical and electrical products, design, manufacturing, application research, operation and management, specialized technical personnel in sales and management work. The students shall conscientiously complete the deepening study of basic theoretical knowledge related to mechanical drawing, design and manufacture, and receive the corresponding basic training in engineering practice. The aim is to have a wide range of professional competencies. First, the basic ability, which requires the development of a comprehensive system for mechanical design and manufacture based on numerical control technology and the basic theories related to automation, so as to achieve a systematic and profound grasp of the technical and theoretical knowledge involved in this major. It covers basic knowledge of mechanical engineering materials and theoretical mechanics, electrical technology and numerical control technology, mechanics of materials and electronics, mechanical design and mechanical principles, hydraulic and pneumatic transmission, etc. Trained to receive basic training from mechanical engineers, with the ability to design and manufacture mechanical products, control equipment, organize and manage production, as well as the necessary professional calculation and drawing, testing and experimentation, Retrieval of literature and operation techniques and other skills; third, the development of the ability of outstanding undergraduate professionals should have a very solid academic foundation and a good artistic foundation, humanities foundation, scientific foundation, text and language expression ability, The self-study ability is strong and the innovation consciousness is remarkable[4].

\section{Analysis on the Teaching Guarantee Measures of Mechanical Design and Manufacture based on NC Technology and the Training Mode of Undergraduate Talents of Automation Specialty}

Strengthen the Construction of Professional Teaching Staff in Colleges and Universities. In the process of talent training, it is very important to perfect and construct the high quality teachers who are optimized in structure and combined with each other, which can be described as the key necessary condition for the reform of teaching. The quality of student training will be directly affected by the practical ability of teachers and the level of academic level. If we want to achieve 
the specific goal of cultivating professional talents and realize the enhancement of students' ability to solve practical problems in engineering, Then the teachers themselves must have strong technical development ability, rich daily production experience, and correctly carry out the relevant training work for teachers of relevant professional teaching and research departments. So that the corresponding teachers of the technical basic course in the teaching and research department can master the specific professional contents comprehensively, and can better apply the technical basic theory to the professional practice. The professional course teacher should realize the goal of teaching reform fully and clearly. For the actual industrial production situation has a more in-depth understanding, fully grasp the industry frontier information, detailed understanding of the process of mechanical processing, scientific and technological R \& D capabilities in mechanical design and manufacturing capacity is strong. On a daily basis, colleges and universities can send several outstanding professional teachers to relevant professional colleges to study 3DCAD and ask them to work hard to obtain professional qualification certificates, and at the same time, In colleges and universities for professional teachers to carry out CAD and NC computer and programming and other corresponding courses to improve learning, strengthen the training of teachers' engineering practice ability and scientific research ability, In each academic year, according to the teaching plan drawn up, teachers are arranged to go to first-line production enterprises to receive modern and advanced engineering practice training. At the same time, they can actively participate in the process of scientific research in enterprises and have experienced unremitting efforts. To achieve the overall training of professional leading teachers, their academic level is relatively high, engineering practice ability is relatively strong and teaching experience is very rich, which can lead the whole team of teachers to participate in the reform and construction of the major; at the same time, This specialized course carries on the reasonable allocation of full-time teachers above the master's degree, and sets up part-time teachers with strong engineering and technical ability and rich practical experience, so as to truly complete the formation of a specialized and integrated contingent of teachers. To be able to employ engineering and technical personnel related to their specialties from enterprises and institutions or from front-line production departments, so that they may concurrently serve as professional teachers, The function is to carry out rational scientific guidance for graduation design and practice[5].

Strengthen the Construction of the Style of Study in Colleges and Universities and Cultivate the Consciousness of Talent Innovation. In the course of teaching reform of mechanical design and manufacture based on numerical control technology and training mode of undergraduate talents of automation specialty, while standardizing teaching process and paying close attention to teaching quality, We should also pay attention to arouse teachers' enthusiasm in teaching and students' enthusiasm in learning, conscientiously develop the two courses of theory teaching and practice teaching, and realize the establishment of the second class of students. For example, the CAD drawing Society and the Mechanical Innovation Association, for example, strive to provide students with relevant places for after-school theoretical study and engineering practice as much as possible, and require teachers of practical training centers to work closely with professional teachers in teaching and research offices. To carry out reasonable guidance and correct guidance to students, to open the training base every day, to create more practical training opportunities for students, to promote students' enthusiasm for autonomous learning by a large margin, and to make the specific goals of teachers and teaching students come true. Based on the smooth development of all kinds of practical activities, teachers' mechanical manufacturing design level is improved and students' practical ability is strengthened. At the same time, it is necessary to deepen the cultivation of students' innovative consciousness. Colleges and universities may formulate a series of special reward policies for the achievements of talents innovation, correctly formulate the training programs for mechanical professionals, and include 12 credits of innovative credits, in order to increase the application of innovative projects to students and publish academic papers. To participate in scientific research projects, to participate in subject competitions, to apply for patents, etc., to consider the interests and interests of students, to realize the robot association, the mechanical innovation association, the 3D cartography association, etc., The establishment and 
implementation of various kinds of association activities, such as the Electronic Innovation Association, should ensure that students are able to achieve practical results in their innovative activities, and equip each association with three to five professional guidance teachers. The purpose of perfecting the relevant teacher reward mechanism is to enable teachers to maintain their work vitality, have a high degree of responsibility, stimulate teachers' enthusiasm for work, and put themselves in the process of students' innovation, in addition, The engineers and technicians of enterprises and institutions can also be actively invited to participate in the guidance of innovative activities as much as possible, so as to deepen the cultivation of students' innovative consciousness[6].

Strengthen the Construction of Teaching Practice Base and Provide Equipment Guarantee. To realize the practical implementation of the joint talent training model between schools and enterprises, to arrange for students in colleges and universities to have at least one year of experience in enterprise apprenticeships and internships during their four years of study, to employ advanced projects in enterprises and institutions so that they can also take up the teaching work of related courses, At the same time, speed up the pace of laboratory construction and substantially increase the funds for the construction of laboratories and practice bases, The hardware condition of the mechanical innovation training center in colleges and universities can be further improved. The laboratory of mechanical disassembly and assembly can also be constructed actively, which is convenient for the students to disassemble and assemble and map the machine tool parts. The application of 3D software to the modeling of disassembly and assembly parts enables students to deeply understand the principles and structures of machine tool parts and measuring tools and to deepen their memory[7]. Colleges and universities can establish a cooperative relationship with many enterprises. Our cooperation with these enterprises is not only to meet the needs of students' internships and staff training, but also to develop in the direction of deep cooperation. To hire engineers and technicians in enterprises to guide students' professional practice and graduation design. On this basis, in order to improve teachers' scientific research ability and engineering practice ability, At the same time, participating in the $\mathrm{R} \& \mathrm{D}$ of scientific research projects of the enterprise, we have realized the cooperative operation mechanism of sharing resources, complementing each other's advantages and mutually beneficial and win-win[8].

\section{Conclusion}

In summary, the mechanical design and manufacture based on numerical control technology and the cultivation of professional talents of automation are the key to promote the higher education in colleges and universities to step into the stage of deepening reform and realize the development of connotation. In this process, colleges and universities should always take the market demand as the main guiding content, promote the overall reform of talent training mode, strengthen the perfect construction of specialized teachers, scientifically plan the professional undergraduate course system, and set up a complete practical teaching platform. After many years of exploration and hard work, colleges and universities should take students as the basis and construct a perfect mechanism for the operation and guarantee of talents, so as to optimize and cultivate the students' innovative thinking consciousness and promote the obvious enhancement of students' ability in engineering practice. The aim of this paper is to achieve the high quality of the good teaching reform and to promote the sustainable development of the quality education in colleges and universities.

\section{Acknowledgement}

In this paper, the research was sponsored by the Reform of Vocational Education and Adult Education Foundation in the Education Department of Jilin Province in 2016 (Project No. 2016ZCY002). 


\section{References}

[1] LI Qiao, XUN Xianhong, WANG Pengcheng. Research on Teaching Reform based on Applied Practice Undergraduate Mechanical Principle[J]Equipment Manufacturing Technology,2017(03).

[2] LIU Xiaohu. A probe into the Transformation of Talent training goals in Local undergraduate Colleges and Universities-Taking the Speciality of Mechanical Design and Manufacture and its Automation in Xinyu College as an example[J].Journal of Xinyu University,2015(02).

[3] YU Wenbo. The Present Situation and Thinking on the Training of Characteristic Excellent Engineers-Taking the Speciality of Petroleum Characteristic Mechanical Design and Manufacture and its Automation Specialty as an example[J].Shandong Industrial Technology,2015(13).

[4] ZHANG Xiuyan, ZHAO Yongmin. A study on the Reform of practical Teaching System for Mechanical Specialty in Private Universities-Mechanical Design and Manufacture and its Automation Specialty[J].China Education Innovation Herald,2014(01).

[5] ZHANG Xiaodong. Research on the Talent training Mode of linking up Education in the Specialty of numerical Control Technology[J].Journal of Guangdong Polytechnic Normal University,2016(05).

[6] PANG Youxia, XU Yan, LIANG Liang, ZHANG Hao, TANG Yong, ZHU Zongming. Research on the Construction of Teaching System of Undergraduate Professional Mechanical Specialty under the Mode of School-Enterprise Cooperation[J].Theory and Practice of Contemporary Education,2010(06).

[7] DU Qiaolian, WANG Xiao, LI Xiaomei. Exploration and Practice of Practical Course Teaching Model for Mechanical Specialty[J].Vocational Education,2013(01).

[8] ZHANG Rong. Research on the Construction of Practical Teaching System for Mechanical Design and Manufacture and its Automation Specialty[J].Examination Weekly,2017(86). 